\title{
How is Social Capital Converted to be Economic Capital? A Case Study from Pesantren's Socio-Economic Projects
}

\author{
M Falikul Isbah \\ Department of Sociology, Faculty of Social and Political Sciences, \\ Universitas Gadjah Mada, Yogyakarta \\ Email: falikul.isbah@ugm.ac.id
}

\begin{abstract}
There is an increasing trend among Indonesian Islamic boarding schools or locally called pesantren to address the socio-economic problems of their neighbouring communities. Over the last two decades, many pesantren have articulated that concern through operating Islamic microfinance business or popularly called BMT (Baitul Maal wat Tamwil) and other enterprise forms. However, the majority of those initiatives are not financially developing. Pesantren Sidogiri is among a few of those exhibit business success and relatively significant social benefits to the Pesantren as well as its graduates. Based on fieldwork findings and the employment of social capital theory, this paper argues that the success of Pesantren Sidogiri's three business hubs (Kopontren Sidogiri, BMT MMU, BMT UGT) is because the Pesantren has successfully mobilised and managed its rich social capital which is embedded in the Pesantren's social networks. That social networks have constantly been managed and developed through appropriable social organisations and closure of social networks. The former is evident in the Pesantren's program of Affiliating Madrasah (madrasah ranting) and Teacher-Internship (guru tugas), while the latter in the Alumni Association (himpunan alumni) and the publication of monthly-Bulletin Sidogiri. These two streams have intentionally or unintentionally provided the Pesantren with a ready-use of social capital to be converted as economic capital in its economic projects.
\end{abstract}

Keywords: pesantren; social capital; economic capital; economic project

\begin{abstract}
Abstrak
Terdapat trend yang meningkat di kalangan pesantren untuk turut menjawab masalah socialekonomi masyarakat di sekitarnya. Dalam dua decade terakhir, banyak pesantren telah mencurahkan perhatian mereka melalui lembaga keuangan Islam atau BMT (Baitul Maal wat Tamwil) dan berbagai bentuk usaha lain. Kendati demikian, mayoritas inisiatif semacam itu tidak berkembang secara keuangan. Pesantren Sidogiri di Pasuruan, Jawa Timur adalah salah satu dari sedikit yang sukses dan menunjukkan kemanfaatan social signifikan bagi Pesantren tersebut beserta alumninya. Berdasarkan temuan riset lapangan dan penggunaan teori modal social, artikel ini berargumen bahwa kesuksesan tiga unit usaha Pesantren Sidogiri (Kopontren Sidogiri, BMT MMU, BMT UGT) adalah karena Pesantren ini berhasil memobilisasi dan mengelola modal sosialnya yang begitu kaya, yang terkandung dalam jaringan social Pesantren ini. Jaringan
\end{abstract}


social ini dikelola dan dikembangkan secara terus-menerus melalui organisasi-organisasi yang dapat diapropiasi dan kelekatan jaringan social. Yang pertama adalah program Pesantren ini dengan Madrasah Ranting dan Guru Tugas, sementara yang kedua adalah himpunan alumni dan penerbitan Bulletin Sidogiri setiap bulan. Dua aras ini baik sengaja atau tidak sengaja telah menyediakan Pesantren ini dengan modal social yang siap-pakai untuk dikonversi menjadi modal ekonomi dalam proyek-proyek ekonomi mereka.

Kata Kunci: pesantren; modal sosial; modal ekonomi; proyek ekonomi,

\section{A. Introduction}

Pesantren are Islamic boarding schools that have been found in Indonesia from precolonial times to the present. In the past, their core business was the provision of Islamic learning for Muslim pupils who had aspirations to later become the propagators of Islam in their home communities. In their current form and under the auspices of present and past Indonesian governments, pesantren have become an important part of the Indonesian national educational system serving a wide populace. Besides their core business in education, increasingly more and more pesantren carry out socio-economic projects, whose aim is to improve the conditions of their neighboring community.

Studies (eq. Sakai 2008; Sakai and Marijan 2008) have suggested that some Indonesian pesantren are using different socio-economic models in the way they conduct community engagement projects. Some of them have established community-based agribusiness projects, small enterprises, cooperatives as well as microfinance businesses. Others manage charity organisations serving their immediate neighbourhood. Two books published by the Indonesian Ministry of Religious Affairs provide an overview of their diverse socio-economic activities. One book titled Pesantren Agrobisnis (Agribusiness Pesantren) draws a picture of the agribusiness model of the economic projects of some pesantren (Proyek Peningkatan Pondok Pesantren 2004), while the other, entitled Pondok Pesantren Agroindustri di Indonesia (Agribusiness Pesantren in Indonesia), illustrates the small-scale industry model of the economic projects of other pesantren (Direktorat Pendidikan Keagamaan dan Pondok Pesantren 2001). Both of these books point to the increasing significance of pesantren socio-economic engagement in community development. However, given that there are more than twenty-seven thousand pesantren throughout the Indonesian archipelago (Direktorat Jenderal Pendidikan Islam 2012), pesantren which manage socio-economic projects are a distinct minority and do not represent the overall picture of Indonesian pesantren.

However, many socio-economic enterprises initiated by pesantren are financially not sustainable due to at least three reasons. Firstly, van Bruinessen and Wajidi (2006) have identified the policy shift among funding agencies from community development projects to political projects, such as civic education, gender, and human rights as part of the reason for their disappearance. Secondly, post-Soeharto political liberalisation has opened spaces for political participation through new political parties. This has provided new opportunities for pesantren people to be involved directly in politics and power struggles to the point where they neglect 
community development activities at grass root level (see Nurhasim and Ridwan 2004). Thirdly, Budiwiranto (2009) has indicated some other reasons: the problem of asset ownership and the relation of mutual dependence between the pesantren kyai and their communities. Most kyai and their families were reluctant to share ownership of pesantren assets, such as cooperatives or small-scale banks. Rather than seeing these assets as communally owned, they saw them as their private property. In cases where such assets are owned by the kyai without any public share, the idea of participatory development with greater benefit to the community becomes difficult to achieve.

In contrast, the economic projects of Pesantren Sidogiri in Pasuruan, East Java is widely recognised as successful financially, and its BMT UGT is currently recorded as the largest microfinance business in Indonesia. Extending studies by Sakai (2008) and Sakai and Marijan (2008) which have implied that the rapid development of the Cooperatives of the Pesantren Sidogiri could be due to its ability to mobilize the available network of the Pesantren's alumni, this study aims to unravel a more detail sociological explanation on how the process of mobilization is carried out. Furthermore, the graduates of pesantren are commonly perceived to be less competitive in the formal labor market, and the question raised is as to what extent the Cooperatives benefit the Pesantren's graduates in providing employment and other business opportunities.

\section{B. Methodology and the Use of Social Capital Theory}

This is a case study research with a qualitative approach in all stages. A qualitative approach was chosen in conjunction with the expected result of the 'process view of social life' on how the actors (people in the Pesantren and Cooperatives) activate the available resources in their social structure or networks for achieving their interests, such as employment and business cooperation (Bryman 1988, p. 140). The case study focuses on the socio-economic role of the Pesantren Sidogiri through its three Cooperatives: the Kopontren Sidogiri, the Cooperative of BMT MMU and the Cooperative of BMT UGT. As a minor research project, two-month fieldwork was conducted in Pasuruan district only, though the business units of the Cooperatives are widespread in other districts and provinces. This did not lessen the significance of the study because its main objective was to explore the characteristics of social relations that generate social capital and how the dynamic exchanges of social capital were carried out amongst the community involved in this issue. Therefore, the use of the social capital concept in this study is arguably relevant to investigate and analyse the rapid growth of that business from the perspective of sociology and social sciences.

For this study, the social capital theory is used in three systematic points of analysis: examining the character of social structure that supports the rapid development of the Pesantren's Cooperatives; exploring the possible forms of social capital found in the community; and investigating the dynamic exchanges of social capital among the actors involved in the activities. These three points were also used to group the data in the coding phase. The data includes publications, interview transcripts, observation notes, and documents that were collected during the fieldwork.

The data analysis then resulted in three groupings of discussion. The first is 'the character of social structure that facilitates the rapid growth of the Cooperatives,' with a focus on two 


\section{Al Izzah: Jurnal Hasil-Hasil Penelitian-ISSN: 1978-9726 (p); 2541-0717 (e)}

Volume 14, Nomor 1 (Mei, 2019)

aspects of social capital: 'appropriable social organizations' and 'closure of social networks.' The second is 'forms of social capital' with three forms being predominant: 'trustworthiness,' 'information channels' and 'norms and effective sanctions.' The third is 'the dynamic exchanges of social capital' with 'bonding and bridging/linking social capital' as the keywords.

\section{Pesantren Sidogiri as a Case Study}

Pesantren Sidogiri is a major and advanced pesantren with a strong influence on many smaller pesantren and madrasah in the region ${ }^{1}$. It has such influence because its advanced education produces kyai and teachers who lead smaller pesantren or teach in smaller madrasah. The example of such graduates is Kyai Haji Abdullah Schal, a charismatic figure who leads a pesantren in Bangkalan, Madura, and Kyai Haji Miftachul Akhyar who became the general chairman of East Java Board of Nahdlatul Ulama, the largest Muslim organization in Indonesia (Ahmad 2006, p.11-14; Yasir 2008, p.56-57).

Bustami (2009, p. 39) notes that there are two versions of the history of the founding of Pesantren Sidogiri. According to the government of Pasuruan Regency, it was in September 1712, but according to the Pesantren, it was on 5 October 1745. It is important to note that the Pesantren is admired as the first pesantren in Pasuruan Regency and its founding is also recognized as the anniversary of the Regency. This indicates its very strong cultural legitimacy among the surrounding community as well as the local government. Also, when Nahdlatul Ulama, the organization of traditionalist Muslims in Indonesia was founded in 1926, the kyai of the Pesantren at that time, Kyai Haji Mas Nawawi was a member of its consultative board.

During the period of this research, the Pesantren was led by Kyai Haji Nawawi Abdul Djalil (Sidogiri 2009, p. 8). The total number of santri was 4261 pupils coming from Pasuruan and surrounding districts which are called Tapal Kuda area, districts in Madura Island and several regions that became the migration destination of Maduranese (Sidogiri 2009, p. 31). It is important to note that the dominant language in the Pesantren is Maduranese, not Javanese language because the eastern part of East Java Province which is popularly called Tapal Kuda area is dominated by Maduranese who migrated to the region in the colonial era. Today, their culture and language predominate mainly along the north coastal area of Tapal Kuda. ${ }^{2}$

The Pesantren conducts its educational process through three sections: schooling in Madrasah Miftahul Ulum, some public lectures (pengajian bandongan), and an advanced study group (kuliah syariah). Madrasah Miftahul Ulum, or MMU, is like a general school but its curriculum is limited to Islamic teachings, ranging from theology, Islamic law, to Arabic. Based

\footnotetext{
1 Dhofier (1999 [1982], p.5) categorized the hierarchy of traditional Islamic education in Java in five levels: Advanced Major Pesantren teaches advanced kitab kuning, and their graduates can act as kyai of a pesantren or senior teacher; Secondary Pesantren teaches elementary kitab kuning, and their graduates can act as a religious teacher or minor kyai for surrounding community; Minor Pesantren teaches only basic text of Islamic teachings, and their graduates cannot become kyai and religious teacher; Pengajian Kitab is a communal and public learning in which a kyai reads a kitab kuning, and the audience listens passively; and Elementary Pengajian Koran is where children of school age learn to read the Koran from a religious teacher in mosque or madrasah.

2 Information about the domination of Maduranese and their culture in the region is based on my observation during the fieldwork, my long friendship with many colleagues from the region, and my frequent travel to the region.
} 
on 2009 data, the schooling system is divided into preparation level (Istidadiyah) with 653 students, primary level (Ibtidaiyah) with 1000 students, elementary level (Tsanawiyah) with 2245 students, and high level (Aliyah) with 640 students. The primary level is conducted in the morning, while the elementary and high levels are conducted in the afternoon. Out of schooltime, the students have to attend a public lecture which usually takes place in the mosque or the house of the kyai. There is possibly more than one public lecture being held by different kyai or senior teachers at the same time, so a student can choose which subject he wants to learn. The highest level is an advanced study group (kuliah syariah) which is intended for students who have graduated from a high level (Aliyah) of the Madrasah. It is a combination of public lectures on certain advanced subjects and a group discussion supervised by the grand kyai directly. At this level students have to be active in showing their understanding and opinion on certain cases based on references received in advance. One hundred and seventeen students were recorded as enrolling in this level in 2009, and most of them were the graduates of high school who were promoted to junior teachers in the Madrasah or members of the Pesantren's caretaker boards (Sidogiri 2009, p. 56-60; 102-106). ${ }^{3}$

In terms of its management pattern, the Pesantren Sidogiri is likely to be different from most other pesantren which rely more on the competence, initiative and authority of a kyai Haji Mahmud Ali Zain, who spent his school years in the Pesantren in the 1960s, and has been serving as a senior teacher and caretaker up to now, describes the management as a combination of 'top-down' and 'bottom-up.' The first means that the kyai has the ultimate authority on everything regarding the Pesantren in the form of permission and control, while the second means that the caretakers are expected to initiate new ideas through a discussion process (musyawarah) among them for improving the Pesantren.

\section{C.1. The Socio-Economic Role of the Pesantren Sidogiri}

Apart from its many activities and institutions in educational affairs, the Pesantren Sidogiri is a growing strength in empowering the social and economic capacity of its teachers, caretakers, and surrounding communities. Its social and economic role is carried out through three business hubs: the Kopontren Sidogiri, the Cooperative of BMT MMU and the Cooperative of BMT UGT. All three business hubs are organized in a cooperative model, in which the organization is carried out by three bodies: caretaker, supervision, and management board. Caretaker board is selected by the members of the Cooperative for a period of service to arrange targets, strategies, and policies. Supervision board usually consists of the family members of the Kyai (Majlis Keluarga) with authority to control all operations of the cooperative. The management board is selected by the members as a task force to realize what has been decided by the caretaker board or suggested by the supervision board. ${ }^{5}$

\section{C.1.a. Kopontren Sidogiri}

\footnotetext{
${ }^{3}$ Other than the written documents referenced, this was reinforced through my observation data.

${ }^{4}$ Dhofier (1999 [1982], p.34-35) notes that pesantren is like a small kingdom (kerajaan kecil) with a kyai as the only source of power and authority. No one can question his decisions except greater kyai whom he respects.

5 Interview with Haji Mahmud Ali Zain, Pasuruan, 23 September 2010.
} 
Kopontren is an acronym of Koperasi Pondok Pesantren or The Cooperative of Pesantren. It is the oldest business hub of Pesantren Sidogiri. When it was initially set up in 1961, it was intended to serve the students through small food stalls and grocery items within the Pesantren area. Then, it was developed to provide loans for the teachers of the Pesantren in a very limited capacity. Today, the Kopontren conducts its business in three sectors: trading, servicing, and manufacturing.

The current Kopontren began in 1997 when Haji Mahmud Ali Zain, one of the senior teachers of the Pesantren started to be involved in its management. He registered its legal license in 1997 that enabled the Kopontren to open its business units outside the Pesantren area ${ }^{6}$. Within the Pesantren, the Kopontren has a growing market as the number of student increases. It is the single player in selling the daily needs of students in the dormitory of the Pesantren through two big food stalls, a café, grocery, laundry outlet, and book store. It also provides stationary and a photocopier, groceries, printing, postal and mobile phone recharge outlets around the Pesantren which enables these to serve both the students and surrounding community. Map 2 shows the cluster of nine business units located within and around the Pesantren.

Since 1997, the Kopontren has been expanding its business network by opening new business units, mostly grocery, in every sub-district in Pasuruan. Starting from 2009, it has expanded to districts such as Banyuwangi and several districts in Madura Island. Today it has 32 units in 7 districts of East Java Province. For a branch or business unit, the Kopontren employs seven workers on average, so with 32 branches, it employs around 230 workers including management and administration staff in its central management office.

In its early days, 85 percent of the Kopontren's shares belonged to the Pesantren, but since 2009 they have been divided so that 50 percent are the Pesantren's and the remaining 50 percent belong to individual members of the Kopontren. This pattern of capital share happens only in the eight branches which are close to the Pesantren and opened before 2009. From 2009, the Kopontren decided to expand its branches as much as possible as a response to the rapid spread of Alfamart and Indomart, the two giants of retail franchises in Indonesia. They are big companies, and their shares are in the hands of multinational companies and big domestic investors. The Kopontren was concerned about unfair practices by such giant franchises which treat communities as consumers only and do not provide them any opportunity to own the shares as well as sell their products ${ }^{7}$. In contrast, the Kopontren arrange a more open and participatory model of share ownership through the cooperative. It provides an open membership to people by paying a small amount as a membership fee and investing their money, the amount of which is based on individual preference. Moreover, it provides more opportunities and spaces to surrounding home industries, such as clothes and sarung, and farmers to sell their products in the groceries.

To open a grocery, the Kopontren needs a starting capital of about 500 million rupiah which can be collected through its capital, joint venture (musyarokah) and fund management (mudlorobah). In 2009, it planned to open five branches; one grocery in the City of Pasuruan,

\footnotetext{
${ }^{6}$ Interview with Haji Mahmud Zain, Pasuruan, 23 September 2010.

7 Interview with Haji Mahmud Ali Zain, the manager of the Kopontren, Pasuruan 23 September 2010, and with M. Luthfillah Habibi, SEI, the assistant manager of the Kopontren Sidogiri, Pasuruan, 29 September 2010.
} 
two groceries in Sumenep, and a grocery in Bangkalan and Pamekasan, respectively. To realize that plan, the central management invited potential alumni and parents of students from the surroundings of the planned locations of the groceries. The function resulted in about 2 billion rupiah through Masyarakat, and the amount was enough to open the five groceries. In Sampang, a group of people organized by the local board of Nahdlatul Ulama also opened a grocery through mudlorobah by which the grocery is branded and managed by the Kopontren while the share holders wait for the expected benefits by the percentage of their shares. ${ }^{8}$

Apart from these developments, the Kopontren also has a mineral water factory with a hundred thousand cartons of production capacity per month. At that time, the factory employed 25 workers and today it employs 140 fulltime workers, 40 percent of whom are the Pesantren's graduates, and the rest are from the surrounding community where the factory is located. For distribution, the management of the factory makes use the network of the Pesantren's alumni to be involved as distributors in their home towns.

\section{C.1.b. The Cooperative of BMT MMU}

The name of BMT MMU (Baitul Mal wat Tamwil Maslahah Mursalah Lil Ummah) ${ }^{9}$ is a word-play on Madrasah Miftahul Ulum, the Pesantren's Islamic school. The most targeted location to open new branches is the traditional market because it is where the usurers operate, and the BMT wants to serve the small traders. Twenty-four of its branches in Pasuruan Districts are located in traditional markets. In 2009, these branches provided small loans which are below 5 million rupiah to 12,000 small traders, while 40,000 customers save their money with them. The monthly capital flow in these branches is calculated at 20 billion rupiah. ${ }^{10}$

Another priority in giving credit is small enterprises that employ a lot of people. It is very selective regarding the credit proposal from big enterprises. Dumairi claims that if the benefits are not going to many people, the BMT would rather give credit to small traders such as bakso or noodle retailers. The smaller or, the needier is given the priority. ${ }^{11}$

The BMT MMU was founded with an initial capital of 13.5 million rupiah from the Cooperative membership fee of the Pesantren's teachers and caretakers (Abidien 2007 ). Now it has branches in every traditional market found in each sub-district in Pasuruan District. At first, it was intended to cover Pasuruan District only, but now the Board has changed the policy to cover all districts in East Java Province. Ten of its 32 branches are located in five other districts in the Province.

The latest data indicate that the monthly capital flow of the BMT is about 60 billion rupiah on average and recorded as the third largest BMT in Indonesia in 2010 by Investor Magazine (Anggreni 2010, p.72-73). It employs around 150 workers consisting of the management and administration staff in its central management office as well as at least four workers in each of its 32 branches. $^{12}$

\footnotetext{
${ }^{8}$ Interview with Haji Mahmud Ali Zain, the manager of the Kopontren Sidogiri, Pasuruan, 23 September 2010.

${ }^{9}$ Maslahah Mursalah Lil Ummah is Arabic meant 'Welfare for the People'

${ }^{10}$ Interview with Haji Dumairi, Pasuruan, 24 September 2010.

${ }^{11}$ Interview with Haji Dumairi, Pasuruan, 24 September 2010.

12 Interview with Haji Dumairi, Pasuruan, 24 September 2010.
} 
Other than its economic aims, the BMT MMU supports the financial needs of the madrasahs and their teachers through loans, fund management, and schematic aids. Another purpose is to eradicate the practices of $r i b a^{13}$ Among communities, mainly small traders who have to borrow some money from usurers. Actually, according to the interview with Haji Dumairi $^{14}$, pesantren and madrasah teach avoidance of the practice of riba and offer Syariahbased economic practices which better protect the small traders or the borrowers. To implement such Syariah-economic principles, he thought that founding a Syariah-based financial institution was the only way. Therefore, the Islamic teachings learned in madrasah are practiced in daily life.

Haji Dumairi is the manager as well as one of the founders. He claims that the most important social aim of the founding of the BMT MMU is to support the Pesantren's AffiliatingMadrasahs. Therefore, its name is a word-play on the Madrasah's name. The Pesantren has 171 Affiliating-Madrasahs located in many sub-districts and districts. Through its continual social fund allocation, the condition of the Affiliating-Madrasah is much better than before. The average salary of the teachers of the Affiliating-Madrasah before the systematic support by the BMT MMU was very low and unstable. There were three patterns of payment. Some of them were paid monthly, about 15 thousand rupiah. Others were paid every harvest season, which occurs every four months because most madrasah are located in rural and agricultural areas, and the students' parents are farmers. When the parents harvest their plantations, such as rice, the students bring 3 kilograms of rice to their madrasahs. The principal then collects the rice to give to each teacher. The other payment method was even less frequent, being when the madrasah organizes a closing teaching term at the end of the year. At that moment, the principal encourages parents to hand up some money; the collected money was then shared by each teacher to the same value ${ }^{15} \mathrm{Also}$, the poor facilities of that madrasah are also part of the concern. Many staff did not have proper offices.

Dumairi expressed his concern regarding the situation of madrasahs in rural areas:

After a long time serving as a teacher of madrasah, I was concerned with their real situation. If not being supported with strong financial capacity, the madrasahs will quickly collapse due to a financial factor. ${ }^{16}$

\section{C.1.c. The Cooperative of BMT UGT}

As with the BMT MMU, the BMT UGT is also a micro finance business with Syariahbased principles. Founded in 2000, it was the result of long discussions, and a participatory survey among the alumni spread in various districts. At that time, some people within the BMT MMU saw the potential to expand such a business. However, they did not want to interrupt the existing plan and concentration of BMT MMU to develop branches, to serve people within Pasuruan District, and to support the welfare of the Affiliating-Madrasah together with their

\footnotetext{
13 Riba is a concept of added value or interest in Islamic law that has to be avoided or combated by Muslims. The practice of riba is commonly found in the banking system through an interest in loan.

14 Interview with Haji Dumairi, Pasuruan, 24 September 2010.

15 Interview with Haji Dumairi, the manager of BMT MMU, Pasuruan, 24 September 2010.

16 Interview with Haji Dumairi, the manager of BMT MMU, Pasuruan, 24 September 2010.
} 
teachers. The Pesantren realized that it had another social network, the receivers of the TeacherInternship program, which could be mobilized for collective economic interests. Therefore, they decided to found a new BMT to cover outside the Pasuruan District, which is the stronghold of BMT MMU. It was called BMT UGT (Usaha Gabungan Terpadu/Collective Enterprise) as a word-play on UGT, the acronym of Urusan Guru Tugas (Teacher-Internship Affairs).

Compared to the other two Cooperatives, the Cooperative of BMT UGT had a faster growth rate with 109 branches by its tenth year, around 143 billion rupiah of monthly capital flow on average, and nearly 1 billion rupiah of monthly benefit on average. It employs more than 440 workers, distributed over 109 branches and a central management office. Given such rapid growth, in late 2009 the management of the BMT MMU and the BMT UGT with the permission of the Kyai released a new policy: the BMT MMU should expand its services to all East Java Provinces and BMT UGT should cover as many provinces as possible, not only East Java province as previously. ${ }^{17}$

Contrary to the BMT MMU that focuses in rural areas, the BMT UGT tries to popularize such Islamic micro finance business in urban areas such as Surabaya, the capital city of East Java Province and Sidoarjo, the industrial area close to Surabaya. Its branch in Surabaya had 1,300 consumers in 2007, while the total consumers of all branches were 13 thousand at the same time (Abidien 2007 ). In 2010, it was recorded as being the largest BMT in Indonesia with total assets of about 154 billion rupiah. It serves loans from 200 thousand rupiah to 50 million rupiah for 48,000 small traders and enterprises. Fifty percent of borrowers are in the trading sector; the rest are in agriculture, fishery, and home industries such as handicraft, clothes, and furniture (Anggreni 2010, p. 72-73).

\section{The Character of Social Structure that Generate Social Capital}

Coleman (1988, p. 105-108) argues that all social relations or social structure may produce volumes of social capital. However, social relations with two major characters generate more volumes of social capital which can be activated and mobilized for individual or collective interests. Indeed, it is a social structure which contains 'appropriable social organizations' and 'closure of social networks'. Based on this argument, the research explores the social structure that facilitates the rapid growth of the business activities of the Pesantren's three Cooperatives as described in the preceding part of this essay. The Pesantren's networks of Affiliating-Madrasah and Teacher-Internship program were identified as being 'appropriable social organizations,' while its effort to consolidate an alumni association and to publish a monthly-Bulletin Sidogiri were important strategies to strengthen its 'closure of social networks.'

Before developing its socio-economic role as seen today, the Pesantren Sidogiri had been offering various programs to strengthen its influence to the networked alumni, surrounding educational institutions and wider society. When the Pesantren, therefore, began to develop and broaden its economic activities in 1997, it gained very strong support from individuals and institutions that shared the feeling of connectedness and loyalty to the Pesantren. The main longlasting programs that are still carried out by the Pesantren and generate increasing volumes of 17 Interview with Haji Mahmud Ali Zain, the Chairman of the Caretaker Board of the BMT UGT, Pasuruan, 27
September 2010, and with Haji Dumairi, the manager of BMT MMU, Pasuruan, 24 September 2010. 
social capital are the Affiliating-Madrasah and Teacher-Internship, which are defined as 'appropriable social organizations' because these pre-existing networks are drawn upon to support and broaden the branches of BMT MMU and BMT UGT. Affiliating-Madrasah is a network of Islamic schools that affiliates to the Pesantren, while Teacher-Internship is an annual program of sending would-be graduate students for a year's teaching-internship in other pesantren or madrasah. Whereas 'the closure of social networks' was consistently maintained and improved through the setting up of the Pesantren's alumni association (IASS) in 2006 together with the publication of the monthly Bulletin Sidogiri from 2005.

\section{D.1. Appropriable Social Organisations}

'Appropriable Social Organizations' are available organizations or networks that can be used for other purposes in a given time. Such practices commonly involve 'multiplex relations' in which a person is likely to be linked to more than one context of relations (Gluckman 1967, in Coleman 1988, p. 108-109). Such practices can be recognized also as a conversion of a form of capital to another form (Bourdieu 1986, p. 51-55), such as the conversion of social capital (social networks) to economic capital (business network). For instance, most teachers of the AffiliatingMadrasah are also involved in business activities of the BMT MMU as employees and members, while the teachers of madrasah that receive Teacher-Internship are also employed by the BMT UGT. Indeed, resources from one relationship are profoundly appropriated for use in another interest: developing the two BMTs.

The research found the network of Affiliating-Madrasah is purposively mobilized for developing the BMT MMU, while the network of Teacher-Internship is purposively mobilized for developing the BMT UGT. These two networks are the 'appropriable social organizations' that have been used by the Pesantren Sidogiri.

\section{D.1.a. Affiliating-Madrasah}

The Pesantren Sidogiri has been strengthening its network with surrounding madrasahs, which is called Affiliating-Madrasah, from 1961 as its concern to support them. Through this program, the Pesantren provides several integrated programs for the Affiliating-Madrasah: organizing collective examinations, assisting and examining the quality of Koran reading among the students, organizing various capacity building programs for their teachers and managers, supervising the process of teaching, assisting the administration and management of the madrasahs, and giving various aids for improving their facilities (Sidogiri 2009, p. 75).

Why are these madrasahs happy to be affiliated with the Pesantren? There is a very strong belief in barokah or seeking a blessing from the respected kyai. The kyai once stated that the students and teachers of Affiliating-Madrasah are the same as those of the Pesantren, that they have equal spiritual status before the kyai. In addition, to maintain the sustainability of the Affiliating-Madrasah, the Pesantren has a policy of not accepting students at primary level from the five surrounding districts. Instead, they are encouraged to finish the primary level in the Affiliating-Madrasah closest to their home, then continue at the higher level in the Pesantren later on. ${ }^{18}$

18 Interview with Ahmad Kholilurrohman, the Principal of Madrasah Ibtidaiyah Miftahul Ulum, Pasuruan, 26 September 2010. 
One of the reasons why the Pesantren set up the BMT MMU was its concern about the poor situation of its Affiliating-Madrasah and their teachers. Many programs aiming to improve the quality of the Affiliating-Madrasah will not be successful unless the welfare of their teachers is addressed. However, various educational programs conducted with the Affiliating-Madrasah could not deal with such economic problems, so that the Pesantren initiated a cooperative using the available network. The 167 madrasahs that are affiliated to the Pesantren are the 'appropriable social organization' that contains very rich social capital encompassing human, capital and cultural resources. Map 5 shows that in every sub-district where the AffiliatingMadrasah is found, there is likely to be a branch of BMT MMU.

In the meantime, the network is strategically appropriated by the Pesantren for initiating and developing the BMT MMU. How is the network appropriated? To open a new branch of the BMT MMU, its central management consults with the teachers of the nearby madrasah regarding the market and capital potentials as well as human resources. If the location is financially promising and the potential human resources are available, the central management recruits at least four teachers from the nearby madrasah as employees to run the branch after receiving intensive training. ${ }^{19}$

The size of the Affiliating-Madrasah network is a product of the Pesantren's investment strategies though its economic purpose was not intended initially. When the network is continually appropriated for developing the BMT MMU, the volume of social capital embedded in the network increases because of the pattern of continuous sociability and series of exchanges in which recognition among the people involved is endlessly affirmed and reaffirmed. Therefore the more social capital is produced and reproduced, the more its volume increases (Bourdieu 1986 , p. 51-55).

\section{D.1.b. Teacher-Internship}

The second 'appropriable social organization' mobilized by the Pesantren for the interest of socio-economic development is its network of madrasah and pesantren that receives TeacherInternship. The network has been appropriated for initiating and developing the BMT UGT. From 1961 (49 years ago) the Pesantren Sidogiri has implemented Teacher-Internships to help madrasahs that needed teachers and to provide opportunities to its graduates to share their knowledge in an educational institution and to have social experiences with surrounding communities. The purpose of the Teacher-Internship program is to advance the quality of these madrasahs and to strengthen the network of the Pesantren with other Islamic-based educational institutions. This program is compulsory for high school graduates as a requirement for obtaining their certificates. There was a story behind this program (Yasin 2007, p. 32).

In the last ten years, the Pesantren has sent around 500 - 700 graduates per year through this program. Recently, 700 madrasahs and pesantrens requested such teacher-internships, but less than 600 graduates were available to send for a year-internship. ${ }^{20}$ At first, the program covered the East Java province only, while today it covers 18 provinces from Aceh to Papua (Sidogiri 2009, p. 14-15).

19 Interview with Haji Dumairi, Pasuruan, 24 September 2010.

${ }^{20}$ Interview with Anshori Huzaimi, the program officer Manager for Teacher-Internship, Pasuruan, 26 September 2010 . 
The internship-teachers have two roles: as a teacher in the madrasah and as a religious priest in the community. To meet these obligations, they attend a preparation workshop for 20 days on how to deal with social life, how to serve among communities wisely, and how to manage a school effectively. As a teacher, they are expected to not only be in the classroom but also support, and be actively involved in, the improvement of the madrasah. To strengthen this purpose, the Pesantren also organizes an annual competition for students of the madrasah that receives the internship-teachers, so their improvement can be monitored. The teachers and managers of the receiving madrasah are also invited to regular workshops in management and teaching improvement (Sidogiri 2009, p. 14-15).

In managing this program, the Pesantren appoints an area coordinator for each district. The area coordinators are mostly respected alumni of the Pesantren Sidogiri living in that area. A madrasah or pesantren which needs an internship-teacher can propose their request to the area coordinator. Before approving such request, the coordinator will survey the location to assure several minimum requirements. Of those is the availability of an educational institution, accommodation and food, the closeness to a worship place, and the availability of supporting funds amounting to 150,000 every month. If all these are met, the host has to collect the internship-teacher, and then, during the residency of the internship-teacher, the host has to send a standardized report every two months regarding the progress of the internship. ${ }^{21}$

According to one of the Pesantren's kyai, the program is expected to be beneficial to the teachers as they have an opportunity to evaluate their capabilities; to the receiving madrasahs as they accept support in improving qualities in teaching and management; and to the Pesantren Sidogiri as it provides chances to broaden and strengthen its network with many Islamic educational institutions in many regions (Yasin 2007, p. 33).

While the network of Affiliating-Madrasah is appropriated for developing the BMT MMU, the network of the teacher-internship program is appropriated for developing the BMT UGT. The same pattern of appropriation also happens when the central management of the BMT UGT opens a new branch and recruits employees from the teachers of the nearby pesantren or madrasah within this network.

\section{D.2. Closure of Social Networks}

The second important character of a social network that is likely to produce rich social capital is a 'closure of social networks.' Coleman (1988, p. 105-108) argues that a network with such character tends to produce collective norms and trustworthiness that generates the proliferation of obligation and expectation among the network members. Otherwise, if the social network is without closure, the norms and sanctions cannot be applied effectively as the individual reputation is less recognized in an open or less dense relationship.

Together with the two appropriable social organizations explained above, the success of the socio-economic role of the Pesantren Sidogiri through its three cooperatives is also arguably due to the closure of social relations among the alumni who have left the Pesantren and lived in their home towns. This study pays special attention to the alumni for two reasons. First, most employees of the three cooperatives are alumni, and the management applies a policy of prioritizing the alumni in recruiting employees. Second, most alumni have left the Pesantren for

${ }^{21}$ Interview with Anshori Huzaimi, Pasuruan, 26 September 2010. 
some time, and they now have their own social, cultural, and economic status in their communities. Such status implies that they have a multiplex relation in which they are related to the alumni network and other networks such as family, religious organization or business group.

This research identified that there are two instruments which maintain and strengthen the closure of the alumni relations both to the Pesantren and among themselves: the Association of the Alumni of the Pesantren Sidogiri (IASS) and the publication of the monthly Bulletin Sidogiri.

\section{D.2.a. IASS: the Alumni Association}

IASS is an acronym of Ikatan Alumni Santri Sidogiri (Association of the Alumni of the Pesantren Sidogiri). The structure of the organization consists of a central board located in the Pesantren office and consulate boards, which represent every district in East Java province and several provinces such as Jakarta, West Kalimantan, and Bali. ${ }^{22}$ The purpose of this organization is to maintain and consolidate close relations and loyalty among the alumni after they have graduated from the Pesantren. Therefore, the emotional spirit of the alumni can be maintained as if they still study and live in the Pesantren.

The common activity, around which most alumni gather in every branch, is collective prayer and public preaching by the kyai of the Pesantren. The central board arranges a regular sermon (pengajian) once a month for every consulate at which the kyai from the Pesantren attends and preaches. ${ }^{23}$ The attendance of kyai attracts the alumni and surrounding community to participate in the public preaching for seeking the blessing from the kyai. This is then followed by a discussion about religious, social and economic issues. The number of people attending such a gathering varies depending on the number of alumni in a given district, ranging from 200 to 500 people. In contrast to other consulates, the Pasuruan consulate organizes such regular gatherings in the Pesantren with about 600-700 people attending (Sidogiri 2009, p. 18-19).

Another typical tradition of such traditional Muslim culture is commemorating the death of a highly respected figure or haul ${ }^{24}$. For the alumni of Pesantren Sidogiri, haul is an important ritual to express their respect and thanks to their passed away kyai by praying together for them. They believe that such rituals maintain their supernatural relations, by which the kyai's blessing is expected. Given such an important meaning, every consulate of IASS always holds haul in the middle of the fasting month (Ramadan) in their districts for which the kyai or the representative of the Pesantren attends and gives a sermon (Husnan 2006, p. 43).

Another activity of the organization is training on life skills, institutional education management, as well as business networking and development. Currently, the central board has set up HASBI (Himpunan Alumni \& Santri Bisnis Indonesia), an association for alumni who work in the business field. It also organizes a plenary reunion once in three years located in the Pesantren at which all alumni attend. ${ }^{25}$

Such programs and activities can proceed well as these are fully funded by the social fund of BMT UGT. For the incoming year of 2011, BMT UGT has allocated 165 billion rupiah

\footnotetext{
22 Interview with Ahmad Dairobi, Deputy Secretary of IASS, Pasuruan, 24 September 2010.

${ }^{23}$ Interview with Ahmad Dairobi, , 24 September 2010.

24. Haul is an Arabic literally means yearly period. Other than a collective praying, such ritual commonly includes a story telling about the greatness of the kyai who is commemorated.

25 Pengurus Pondok Pesantren Sidogiri, Tamasya/Annual Report, 8, 1430-1431 H/2009, p. 18-19
} 


\section{Al Izzah: Jurnal Hasil-Hasil Penelitian-ISSN: 1978-9726 (p); 2541-0717 (e)}

Volume 14, Nomor 1 (Mei, 2019)

for the regular gathering, mainly for travel expenses of the Kyai. Therefore, the consulates of IASS that host the gatherings do not need to provide any expenses, only the food to share. ${ }^{26}$

The vision of this organization is "a dedication to the Pesantren and the society. ${ }^{27}$ This vision is applied in its programs that are categorized into four divisions: education and training, propagation and social, legal assistance, and economics and business. Through these four divisions, the Pesantren mobilizes its alumni in various regions to dedicate their time and capacities to the Pesantren and their surrounding society. For instance, for those who have more interest in business, the Pesantren encourages them to be involved in developing the Pesantren's business network, while for those who have more interest in education or preaching, the Pesantren encourages them to be a teacher or a kyai. According to Haji Dumairi, to be a businessman, a teacher, or a kyai is the same honor before the Pesantren and Islam as long as it is intended as self-dedication to the Pesantren and society. ${ }^{28}$

\section{D.2.b. The Publication of Bulletin Sidogiri}

Bulletin Sidogiri is the most important publication by the Pesantren. It has been published monthly since 2005 as an interacting media between the Pesantren and its alumni as well as wider communities that they can recognize and understand what has been done by the Pesantren. The initial edition was published in 40 pages and 3000 copies, it has then increased steadily. Currently, it has 120 pages and prints 10,000 copies. The distribution of the Bulletin is through consulate boards of IASS in every district and province as well as through private distributors and book stores. According to one of the editors, it is estimated around 40 percent of the readers are the alumni of the Pesantren, while the rest are the general public. ${ }^{29}$

There are important rubrics that play as an interacting medium between the Pesantren and the readers. Of those is Pengajian in which the leader of the pesantren answers written questions from the readers on theology and other religious subjects. This rubric provides chances to the readers who are mostly the alumni to remain learning and interacting with their guru. Another is Pesantrenku which provides information on the current activities and policies of the Pesantren that the alumni living far away from Pasuruan can keep in touch with the current development of their Pesantren. Therefore, they can contribute to the Pesantren in line with the information they receive. The other rubric is Reuni which explores figures of alumni have made significant contributions to their surrounding communities behind their weakness in other aspects of life, such as economic capabilities.

Both the alumni association and the publication of Bulletin Sidogiri are the Pesantren's efforts to maintain and strengthen bounded solidarity among them. Bounded solidarity is a shared feeling among individuals to identify themselves as members of a group, sect, or community beyond the existing differences and stratification (Portes 1998, p. 7-9). Indeed, some alumni might be rich and posses a high status in the community, while others might be the

\footnotetext{
26 Interview with Ahmad Dairobi, Deputy Secretary of IASS, Pasuruan, 24 September 2010, and Dumairi, General Manager of BMT MMU, Pasuruan, 24 September 2010.

27" Haji Mahmud stated the vision in Arabic "khidmatun lil ma'had wa lil ummah." Interview with Haji Mahmud Ali Zain, Pasuruan, 23 September 2010.

28 Interview with Haji Dumairi, Pasuruan, 24 September 2010.

${ }^{29}$ Interview with Masyhuri Mochtar, one of the editors of Bulletin Sidogiri, Pasuruan, 24 September 2010.
} 
opposite. The bounded solidarity encourages them to take part in the same activity: developing the Cooperatives. Their participation varies in line with their social and economic status. The fresh, less wealthy, graduates are likely to participate by becoming employees of the Cooperatives, the small and medium entrepreneurs tend to be trusted creditors, and the rich are likely to be generous investors.

The closure of their social relations eventually generates more collective norms and trustworthiness that allows the proliferation of obligation and expectation among them (Coleman 1988, p. 105-108). Dumairi, the manager of BMT MMU, explained that all the Pesantren's business hubs prioritize the alumni in recruiting employees because they are 'easier to command. ${ }^{30}$ The leaders and managers are aware that the Pesantren's alumni are not skillful to do the job, but they believe that they are more reliable to have such a responsibility. Such belief is based on some assumptions. First, the alumni are bounded in the same social relations: the alumni association, so their reputation is monitored by all members of the network. Second, they had been educated in the Pesantren for a long period and are expected to be truthful (shidiq) and trusted (amanah). Third, they need the job and income, so they are unlikely to abuse their positions.

What we see as the strength of our Pesantren's graduates is their honesty and trust, by which they try to be responsible for the jobs we give though they are not skillful in that. How to create them skillful is an easy thing. They can be trained in only a month. ${ }^{31}$

Thus, collective norms and trustworthiness are likely to be easily produced among the graduates because an individual's reputation is strongly recognizable in these types of dense relationships, such that effective sanctions can be easily applied.

\section{E. Conclusion}

The findings of this study indicate that the Pesantren Sidogiri has been successful in strengthening and broadening its socio-economic role by developing three Cooperatives: the Kopontren Sidogiri, the BMT MMU, and the BMT UGT. The rapid growth of these three Cooperatives is arguably due to the Pesantren's success in managing and mobilizing its social capital. This case study found that the Pesantren Sidogiri has been consistently investing to broaden its network through its program of Affiliating-Madrasah and Teacher-Internship. The network eventually becomes a social structure in which rich social capital is available to be mobilized for economic purposes.

The social structure that facilitates the development of rich social capital was seen to be the availability of 'appropriable social organizations' and the 'closure of social networks'. 'Appropriable social organizations' were evident in the Pesantren's long-lasting strategic investment through the program of Affiliating Madrasah and Teacher Internship. These two programs, originally intended to help minor madrasah or pesantren to improve their qualities in teaching religious subjects, have become available networks that are mobilized by the Pesantren for collective economic interest. The network of Affiliating Madrasah has been systematically

\footnotetext{
30 Interview with Haji Dumairi, Pasuruan, 24 September 2010.

31 Interview with Saifullah Naji, the Secretary of the Pesantren Caretaker Board, Pasuruan, 27 September 2010.
} 
activated for developing the Cooperative of BMT MMU, while the network of Teacher Internship has been strategically mobilized for developing the Cooperative of BMT UGT.

Along with these two appropriable social organizations, the Pesantren also consistently engages in practices associated with the 'closure of social networks'. There were two main instruments used to maintain and strengthen the closure: the Pesantren's alumni association (IASS) and the publication of monthly-Bulletin Sidogiri. The alumni association helps to maintain the loyalty of the wide spread alumni and synergize their potentials, particularly in supporting the development of the Pesantren's Cooperatives. The monthly-Bulletin Sidogiri functions as an important communication medium between the kyai, the Pesantren, and the alumni who have left the Pesantren. By maintaining closure, the Pesantren can more easily mobilize the alumni for any purposes, including developing the Cooperatives.

The activities of the Cooperatives produce and reproduce social capital. Three forms of social capital emerged: 'trustworthiness', 'norms and effective sanctions' and 'information channels'. These were dynamically exchanged by members of the community with their acquaintances from inside and outside the networks through 'bonding social capital' and 'bridging or linking social capital.' The first was evident in the Cooperatives' policy of fulfilling every vacancy by prioritizing the graduates of the Pesantren, in providing chances for the Pesantren's inner networks to become business partners, and in distributing their financial benefit to the Pesantren and its inner networks. Bonding social capital was used by the Pesantren's graduates to gain jobs and convert their social capital into economic capital. In the open job market, they would compete with graduates of secular schools, who are commonly perceived as being more competitive. Such policy also gives the Cooperatives a more secure work environment because most employees are culturally and socially bound to the Pesantren. The norm of trust is maintained because an individual reputation is strongly admired in such a densely integrated community. Meanwhile, employees have high job security as they are not worried about being fired because they have a direct employment relation, rather than being outsourced, and the business operates well. Such a strong social capital in the form of shared norms of trust and reciprocity create a mutual benefit between the Cooperatives and their employees.

Bridging or linking social capital occurred in the ways the Cooperatives synergized the alumni potentials in the interest of broadening their business networks. Such practice is mediated by the alumni who possess multiple relations: relation to the Pesantren/Cooperatives and relation to other networks or organizations. It also occurred in the context of improving the Pesantren/Cooperatives' human resources by making cooperation with experts and other educational institutions specializing in Syariah-based business and economics.

I argue that the Cooperatives tend to utilize 'bonding social capital' in recruiting employees and distributing other benefits of the Cooperatives, but tend to 'bridge and link social capital' in improving its business and management capacity by making relations with outer networks. Therefore, the Cooperatives have been facilitating the ability of members of the Pesantren networks 'to get by' easier and open up more opportunities to improve their skills and capacity through making contacts with others. This reflects Narayan and Woolcock's (2000, p. 10) suggestion that empirical studies should identify the conditions under which the many positive aspects of 'bonding' social capital within the community that can be mobilized and its 


\section{Al Izzah: Jurnal Hasil-Hasil Penelitian-ISSN: 1978-9726 (p); 2541-0717 (e) Volume 14, Nomor 1 (Mei, 2019)}

integrity can be maintained, while simultaneously helping the members of the community gain access to a more diverse stock of 'bridging' and 'linking' social capital.

\section{Daftar Pustaka}

Abidien, Z., 2007. Mesin Uang Kaum Sarungan (the money machine of Sarungan Commmunity). Tempointeraktif. Tempo, Jakarta. Retrivied November 4, 2010 (http://majalah.tempointeraktif.com/id/arsip/2007/06/04/EB/mbm.20070604.EB124124.id.html)

Ahmad, M. 2006. Wawancara dengan KH Miftachul Akhyar (An Interview with KH. Miftachul Akhyar). Bulletin Sidogiri. Pondok Pesantren Sidogiri Pasuruan, Pasuruan.

Anggreni, P (2010). 5 Ribu BMT 5 Juta Usaha Mikro (5 Thousand BMT 5 Million Small Enterprises), Investor, XII (207) (2010), 72-73.

Babbie, E (2007). The Practice of Social Research; Eleventh Edition. Belmont: Thomson Wadsworth.

Budiwiranto, Bambang (2009). Pesantren and Participatory Development: The Case of the Pesantren Maslakul Huda of Kajen, Pati, Central Java. Journal of Indonesian Islam, 03 (02), 267-296.

Bourdieu, P (1986). The Forms of Capital. In: J. E. Richardson (Ed), Handbook of the theory of research for the sociology of education. New York: Greenword Press.

Bryman, A (1988). Quantity and Quality of Social Research. London: Unwin Hyman.

Bustami, A. L (2009). Kiai Politik Politik Kiai (The Political Kiai - The Politics of Kiai). Malang: Pustaka Bayan.

Coleman, J. S (1988). Social capital in the creation of human capital. The American Journal of Sociology, 94, 95-120.

Direktorat Pendidikan Keagamaan dan Pondok Pesantren (2001). Pondok Pesantren Agro Industri Di Indonesia. Jakarta: Direktorat Jenderal Kelembagaan Agama Islam. Departemen Agama Republik Indonesia.

Direktorat Jenderal Pendidikan Islam (2012). Analisis Dan Interpretasi Data Pada Pondok Pesantren, Madrasah Diniyah (Madin), Taman Pendidikan Qur (TPQ), Tahun Pelajaran 2011-2012. Jakarta: Kementerian Agama RI.

Dhofier, Z (1999 [1982]). The Pesantren Tradition: the Role of Kyai in the Maintenance of Traditional Islam in Java. Arizona: Arizona State University. 


\section{Al Izzah: Jurnal Hasil-Hasil Penelitian-ISSN: 1978-9726 (p); 2541-0717 (e) Volume 14, Nomor 1 (Mei, 2019)}

Husnan, U. 2006. Libur Ramadlan, ISS Adakan Haul Masyayikh and Pesrom. Buletin Sidogiri. Pondok Pesantren Sidogiri Pasuruan, Pasuruan.

Narayan, D. \& Woolcock, M (2000). Social capital: implications for development theory, research, and policy. World Bank Research Observer, World Bank.

www.publicpolicy.umb.edu/ pubpol/.../Woolkock-Week11_001.pdf

Nurhasim, A. and Nur Khalik Ridwan (2004). Demoralisasi Khittah NU Dan Pembaruan. Yogyakarta: Pustaka Tokoh Bangsa.

Portes, A (1998). Social capital: Its origins and applications in modern sociology. Annual Review of Sociology 24 (1998).

Sakai, M (2008). Community development through Islamic microfinance: Serving the financial needs of the poor in a viable way. In Expressing Islam: religious life and politics in Indonesia. Fealy, G. \& White, S., Institute of Southeast Asian Studies, Singapore.

Sakai, M. \& Marijan, K (2008). Harnessing Islamic Microfinance. Australia Indonesia Governance Research Partnership, Crawford School of Economics and Government, ANU College of Asia and the Pacific, The Australian National University, Canberra.

http://www.aigrp.anu.edu.au/publications/briefs.php

Sidogiri, P. P. P (2009). Laporan Tahunan Pengurus Pondok Pesantren Sidogiri (Annual Report of the Caretaker of Pondok Pesantren Sidogiri). Pasuruan: Pondok Pesantren Sidogiri Pasuruan.

van Bruinessen, Martin and Farid Wajidi (2006). Syu'Un Ijtima'Iyah and the Kiai Rakyat: Traditionalist Islam, Civil Society and Social Concerns. In: Nordholt, H.S. Indonesian Transitions. Yogyakarta: Pustaka Pelajar.

Yasin, N. H. (2007). Urusan GT \& Dai: Kaderisasi Penerus Misi Nabi (Teacher Internship and Preacher: Generating Cadres for Sustaining the Prophet Missions). Ijtihad. Pondok Pesantren Sidogiri, Pasuruan.

Yasir, A. (2008). KHS Abdullah Schal, Ulama Kharismatik (KHS Abdullah Schal, a charismatic priest). Buletin Sidogiri. Pasuruan: Pondok Pesantren Sidogiri. 